\title{
Stage 0 Bladder Urothelial Carcinoma AJCC v6 and v7
}

National Cancer Institute

\section{Source}

National Cancer Institute. Stage O Bladder Urothelial Carcinoma A/CC v6 and v7. NCI

Thesaurus. Code C6188.

Stage 0 includes: $\mathrm{Oa}(\mathrm{Ta}, \mathrm{NO}, \mathrm{MO})$; 0 is ( $\mathrm{T}$ is, $\mathrm{NO}, \mathrm{MO})$. Ta: Noninvasive papillary carcinoma.

Tis: Carcinoma in situ: "flat tumor". N0: No regional lymph node metastasis. M0: No distant metastasis. (AJCC 6th and 7th eds.) 